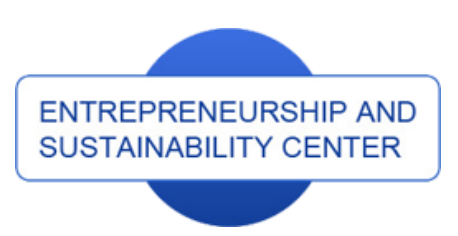

Publisher

http://jssidoi.org/esc/home enterprise

europe

network

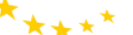

Business Support on Your Doorstep

\section{Scopus}

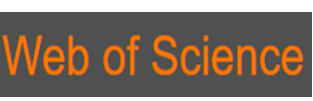

Clarivate
Analytics

\title{
ACCEPTANCE CRITERION OF STATE COERCION IN CONTEMPORARY SOCIETY
}

\author{
Olga Finogentova ${ }^{1}$, Vasiliy Tokarev², Mikhail Petrenko ${ }^{3}$, Tatyana Primak ${ }^{4}$ \\ ${ }^{1,4}$ Institute of Law, Immanuel Kant Baltic Federal University, Kaliningrad, Russia \\ ${ }^{2}$ Samara State Regional Academy, Samara, Russia \\ ${ }^{3}$ International Market Institute, Samara, Russia \\ E-mails:1. finogentovaoe@mail.ru ; ${ }^{2}$ basiletok@gmail.com $;{ }^{3}$ petmn@list.ru; ${ }^{4}$ finogentovaoe@mail.ru \\ Received 12 July 2018; accepted 16 October 2018; published 30 December 2018
}

\begin{abstract}
The article presents acceptance criterion of the state coercion as a form of power realization. According to authors, essential signs of the state coercion, firstly, are functionaries and state authorities representing the society that in turn, legitimizing this state, secondly, the state coercion mediacy by the right. Its social nature causes understanding the state coercion as a legal relation that coercive and coerced subjects, authorized with certain rights and duties, enter. The authorization of subjects, in relation to which enforcement actions are applied, with legal rights and duties testifies to the legal conditionality of state coercion. As a result, it must satisfy the requirements of legality, legitimacy and justice at both levels of the legal system - sectoral and intersectoral - and at all stages of the process of its implementation. The general acceptance criterion of the state coercion is provided to recognize the conformity of its application to the requirements of justice as a moral category. Structural elements of this criterion are validity and proportionality. Their differentiation in content makes it possible to assert that the state coercion should be based on the law (validity) and correlated with individualizing circumstances, which allowing to correct the influence of the coercive on the coerced taking into account the specifics of the concrete case (proportionality).
\end{abstract}

Keywords: coercion; justice; validity; proportionality; legal right; legitimacy

Reference to this paper should be made as follows: Finogentova, O.; Tokarev, V.; Petrenko, M.; Primak, T. 2018. Acceptance criterion of state coercion in contemporary society, Entrepreneurship and Sustainability Issues 6(2): 820-829. http://doi.org/10.9770/jesi.2018.6.2(23)

JEL Classifications: K000

Additional disciplines: law

\section{Introduction}

Questions that are related to the definition of the nature of state power and coercion, their essential signs, foundations, limits and methods of their application are central to the theory of law and for the practice of government control. Therefore, they have always been the focus of attention of legal science representatives. Especially if scientists looked through a boarder lens of legal positivism and used the methodologies of other disciplines: philosophy, sociology, political science, etc. 
We proceed from the premise that the state coercion is characterized by a clash of interests between the state as a main institute of a political power that has significant resources, and the subject or subjects that are opposed to it, and have a substantially smaller reserve of resources. At the same time, the state cannot claim a democratic and a legal status, if its legislation does not define acceptance criterion of the state coercion (Bingham, 2011), (Ambrose, 2014), (Tyler, 1990).

This is about such characteristics of state coercion in the presence of which, it is recognized by society as acceptable. Thus, our approach fully corresponds to the humanistic concept of the state and law functioning, according to which the person, his rights and freedoms are recognized as the supreme value of modern society. At the same time, the coercion should not represent an effective legal system always though it can be also estimated as a necessary element of this system (Lloyd, 1991), (Yankah, 2007-2008), (Zwolinski, 2015), (Kuril, 2018).

In this article we will consistently consider the following aspects of the acceptance of state coercion in modern society: 1) the concept of justice as the main acceptance criterion of the state coercion (Armstrong, 2009), (Munger, 2012); 2) the goal-means ratio in the structure of the justice concept (Gargarella, 2011), (Valentini, 2011); 3) the legitimacy of the state coercion (Green, 2015), (Hardin, 1989-1990), (Ripstein, 2004).

\section{Methodology}

The methodology of our research is determined by the peculiarities of its subject matter. We use a set of methods in the context of systematic approach to the phenomenon of state coercion in modern society. First of all, the usage of the dialectical method and the method of formal logic helps to define characteristic features, systemic connections, grounds, and general criteria for the admissibility of state coercion (Hughes, 2013), (Lamond, 2001), (Leiser, 2008), (Raponi, 2015). In addition, the usage of the systemic method makes it possible to determine the place of state coercion among the methods for implementing state power (Schauer, 2014), (Stavropoulos, 2009). Finally, we adhere to a sociological approach to the study of the state and law to analyze a state coercion as a social phenomenon (Arneson, 2003), (Wollner, 2011).

Of course, the historical legacy of philosophers, political scientists and jurists of the past is not remained beyond our research. We pay special attention to fundamental conceptions of justice, proportionality and legitimacy of coercion, developed by Th. Hobbes, Ch.L. Montesquieu, Kant and M. Weber. At the same time, we share views of contemporary critics of positivist concepts of state coercion (Himma, 2012). Therefore, we often refer to the works of L. Fuller, D. Lloyd and J. Finnis (Fuller, 1969), (Finnis, 2011).

\section{Justice is the main acceptance criterion of the state coercion in the modern society}

To begin with, the society is eventually the coercive subject in the exercise of state power. Using the mechanism of the state to achieve general goals, it appraises the advisability of using coercion in a specific situation. The criterion that society enjoys in such cases is its members' concept about the conformity of the exercise of public power procedures in the form of state coercion with their ideals. From this point of view, the implementation of the state coercion must comply the requirements of morality and the rules of conduct determined by these requirements. So, the state authority and the official, who apply the rules of law in the process of implementing coercive measures, are limited by the principles of moral acceptability, i.e. a certain "minimum of morality". In other words, the acceptability of the state coercion is determined, in particular, by moral requirements. They are like a system of provisions, prescriptions and guidelines that correspond to the national culture and form the boundaries of state coercion: humanity, personal dignity, conscience, justice, honor, duty, conscientiousness. 


\section{The International Journal}

ENTREPRENEURSHIP AND SUSTAINABILITY ISSUES

ISSN 2345-0282 (online) http://jssidoi.org/jesi/

2018 Volume 6 Number 2 (December)

http://doi.org/10.9770/jesi.2018.6.2(23)

However, the understanding of morality as the acceptance criterion of the state coercion is not entirely correct. The morality, as in its ordinary understanding and in the special definition offered by philosophers, is characterized by the breadth of coverage of the relations regulated by its norms. Therefore, it is necessary to use more concrete, in comparison with morality, concept, namely, the notion of the justice.

The justice in the ordinary sense is determined through a category of "impartiality", which is private category in relation to morality. From the perspective of philosophy, it is understood as a way to justify the distribution of profits and burdens between individuals that coexist within a single social space. In our opinion, the notion of justice is more specific than the concept of morality, and it also contains an explicit reference to the regulation of asymmetric relations between the coercive and the coerced. At the same time, such an evaluation criterion of the measures of state coercion application as proportionality plays center stage, reflecting the requirement of coercive justice. In general, we are talking about the correspondence between the negative consequences of coercion and the public danger of a committed act.

In our opinion, the exercise of state power in the form of the state coercion must be carried out in terms of its correlation (proportionality) with the danger that comes to the coercive person from the coerced one. The power influence in the form of the state coercion should not be excessive, i.e. it should prevent the excessive cruelty in relation to the coerced subject or subjects, or, conversely, excessive gentleness. The excessive or too mild coercion is able to initiate a tendency of delegitimation in society, as the coercive subject, concerning the mechanism of the state due to the dissatisfaction with its functioning. It can be caused by the violation of rights and freedoms both the certain person, and society in general, or by unreasonably severe measures of coercion and their application, or by disproportionately mild coercive measures and their implementation or evasion (Mishenin et al. 2018; Načisčionis et al. 2018; Tvaronavičienè, 2018). These tendencies can even lead to the state death, resulting in the certain level of justice in a society, that the state guarantees and protects, can't be maintained.

It should also be noted, that the proportionality can be identified with the law of talion, i.e. requiring compensation equal for an equal and in this sense proportioned. Although, we are of the opinion, that this understanding has no relation to the idea of justice as the acceptance criterion of coercion in the exercise of state power in modern society.

First, the law of talion ("an eye for an eye, a tooth for a tooth"), for all its seeming justice, in fact, cannot fully take into account all circumstances that individualize a particular situation. Second, as John Finnis correctly notes, this law is aimed at the material content or consequences of criminal acts, and not on their formal illegitimacy (dishonesty) (Finnis, 2011, 210-236). Therefore, the law of talion does not provide the reference of existing circumstances in their entirety with the content of the prevailing moral ideal in society. It also, in fact, does not condemn preference cases of the personal interest over the public welfare.

We believe that the proportion, considered in relation to the item of acceptance criterion of the state coercion in its sense is closer to the principle of repression economy offered by Charles Louis Montesquieu in the 18th century. According to VI and XII books of "The Spirit of Laws" analyzing, French enlightener noted, "Combined utilitarian, retributivist and liberal themes in his approach to punishment, while locating the fundamental justification for the right to punish capital crimes in the retributivist rationale of doing justice. As noted by Beccaria and numerous others whom he influenced, moderation in punishments and decriminalization of religious offences were key themes in his discussions" (Carrithers, 1998). The essence of this approach is the interdependence between the intensity of state coercion and circumstances of the case in its entirety. Where the entirety is defined in the context with the concept of justice existing in a particular society. 


\section{The International Journal}

ENTREPRENEURSHIP AND SUSTAINABILITY ISSUES

ISSN 2345-0282 (online) http://jssidoi.org/jesi/

2018 Volume 6 Number 2 (December)

http://doi.org/10.9770/jesi.2018.6.2(23)

Therefore, the proportionality of the applied measures of the state coercion and of the offending behavior by the coerced subject is a sufficiently effective criterion that allows us to draw the line between the permissible and the inadmissible coercion. Although, the justice does not mean only proportion. As another structural element of justice, as the acceptance criterion of state coercion, the validity of its application can be called. This is the state's right to act on behalf of society in order to achieve its goals, or, in other words, the state's authorization (its agencies and officials) by society to implement state coercion.

As we noted above, the society is the coercive subject in implementing measures of state coercion acting through the mechanism of state, expressing its will, therefore ultimately the society empowers the state to consider the application of concrete coercive measures. It seems clear that the state's lack of such a right automatically makes illegitimate the decision taken by it on the application of measures of state coercion.

However, this is not only about the fact that the state has the opportunity to exercise coercion delegated to it by society, but also about reasons and the usage procedure of specific coercive measures, their content. In this sense, the coercion justification as a structural element of justice is the validity of state coercion with the right, which is corresponding to the notions of morality prevailing in a given society. The distinction between justification and proportion need to be drawn in such a way as to include in the content of justification the validity of coercion by the right, broadly understood as a "general social right", and to the content of proportion - the correlation of state coercion with specific circumstances. That allows correcting the impact on the coerced person in accordance with the proposed options, but in the light of specific features in a particular case. Thus, it should be recognized that a moral category of justice consisting of proportionality and justification is a general acceptance criterion of the state coercion. The state organization is established initially as a fact, but gradually it is more and more filled with the principles of right, not because of free self-restraint or self-binding of the power, but on account of its external restriction regulating by the power and society cooperation. These restrictions emerge, grow in number and get stronger with the growth of social consciousness. At the same time, during the cultural development of society, the principle about the worth of the human person is formulated. It means, on the one hand, the mandatory justification displays of state power, which includes the form of coercion, and on the other hand, the legitimacy of the individual's behavior.

\section{Path - goal approach in the structure of the justice concept}

Considering justice as a moral category, lawyers and philosophers differently decide the question of the relationship in the structure of this concept of goals and means. Known approaches to its solution can be divided into two groups: 1) related to the goal-dominating paradigm that expressed in principle "the end justifies the means"; 2) relating to the paradigm of abstract humanism, according to which the means are autonomous. Among supporters of the first approach can be mentioned such philosophers as Jeremy Bentham, John Stuart Mill, Friedrich Nietzsche, Ludwig Andreas von Feuerbach, Jens Timmermann, and others, and the supporters of the second one are Immanuel Kant, Vladimir Soloviev, etc. Depending on the approach that we choose, the value accents are changed either to the subjective rights and human freedoms, his legitimate interests, or to the side of social order.

Thereby the question about the path-goal approach in the sphere of the state coercion implementation should be understood as a question of the content of existing moral priority (ideal) that the coercive subject (society) has at a particular moment. In this capacity, a person with his rights and freedoms may act or the tasks of securing the social order.

However, it is obvious that the choice in favor of one of these two approaches does not mean a complete rejection of the another one. Otherwise, the value of either human life or social order is questioned. Both can lead to 
The International Journal

ENTREPRENEURSHIP AND SUSTAINABILITY ISSUES

ISSN 2345-0282 (online) http://jssidoi.org/jesi/

2018 Volume 6 Number 2 (December)

http://doi.org/10.9770/jesi.2018.6.2(23)

negative consequences for society: to its degradation due to the egocentrism of society members and subsequent anarchy or to a reduction in their number. At the same time, these negative consequences are closely interrelated. Consequently, the shift in value accents always means preservation of a certain minimum volume of each element of social ideal, both individual and collective. In other words, the state coercion implementation requires to proceed from the need of ensuring the minimum volume of the rights and freedoms of the coerced subject and the social order provided by law in any case.

In general, as Dennis Lloyd correctly notes, the purpose of legal science is precisely to adapt traditional concepts to the new conditions of society by refusing the definition of right, in which the role of coercion was emphasized or denied. Instead of this, a systematic evaluation of the coercion forms and its place in the system of social relations regulated by the rules of law, is necessary. Such a research, which takes into account the evolution of human relationships, may lead to a revision of models and concepts, in relation of which the ideas of law and coercion should be analyzed. In other words, the modern theory of law requires a dynamic rather than a static approach (Lloyd, 1991, p. 45).

Meanwhile, there is a widely known conception of state coercion, according to which attention is focused on achieving the goal that faces the ruler, without any regard to other conditions. For instance, M. Weber argued that, in fact, the power's entity presumes probability that the subject is able to realize his will in social respect despite of any resistance. At that it does not matter, what are the grounds for this probability. At the same time, M. Weber unequivocally defined the state as a form of legitimate domination, that is, he introduced a different ("nonviolent") dimension in the notion of power (Weber, Parsons, Henderson, 2012, 74-76; Tvaronavičienė, Gatautis, 2017).

Of course, this approach is based on a serious intellectual tradition of understanding power not only and not so much as a form of limiting the freedom of individuals and / or forcing them to take acts, acceptable to the holders (representatives) of power, but rather as a political strategy, which is aimed to achieving their goals. For example, English philosopher T. Hobbes defines the power as a means for man to achieve the good in the future, i.e. the presence of a subordinate person is not mandatory. Following this conception, it is necessary to go until the end and suppose an existence of some kind of power even in cases, when there is no relationship between the ruler and the subordinate subject. However, such a conclusion is in contrary to the social understanding of power and therefore is divorced from the reality.

In our opinion, the power has a social nature, because it is based on the interaction of individuals and groups. A key concept to define power in this sense is a notion of the will. First of all, originally the power relationships are the conflict relationships. This fact was emphasized, for example, by I. Kant and M. Weber, who pointed out such feature of the power as the resistance from a subordinate subject. However, the resistance can only arise in conditions of a conflict between the interacting parties.

Indeed, if we assume the opposite and suppose that power exists in conditions of the absence of a conflict, when a subordinate subject willingly obeys orders of a ruler and acts to achieve ruler's goals, then it is necessary to state that there is a contradiction between the scientific understanding of power and its ordinary interpretation, which points out an inseparability of the power from the subordination, because the conflict is immanently inherent to subordination. As a rule, the conflict is a clash of different goals of parties, which are fixed in rigid forms. From this it follows that social actors face goals, which they are well conscious. In addition, there is a collision between interacting persons for the implementation of their goals. At the same time, the acceptance of the state coercion should not be reduced to the fact of its compliance to the right. It is known that the right is characterized by such a significant parameter as the need for a considerable period of time for its formation, as well as for the emergence 
of a tradition of its observance in a particular society. But, is it possible to assess the use of coercive measures by the state publicly outside formalized procedures?

The conformity of specific measures of state coercion to the moral ideals of society can be assessed by the society, also directly expressing one's attitude towards them in specific cases. Forms of prompt expression of their attitude to the moral validity of coercive measures adopted by the state may be collective petitions (requests) for pardon (finding of innocence, relief from punishment, etc.) of a person complimented by the immorality of state coercion measures applying against him. They can be submitted to authorized state bodies and officials both in the course of public events (citizens' meetings, pickets, demonstrations, etc.), and in other ways.

\section{Legitimacy of the state coercion in democratic society}

As questions of the bases, acceptance and specifics of the state coercion measures have to be considered in democratic society in the context of legitimacy problems of such coercion, we will make several remarks. The first of them concerns a peculiar economic calculation at distribution of the coercive, imperative power energy in the course of the public relations regulation on the basis and according to the right.

On the one hand, public authorities and officials can and should apply coercive measures against real or potential offenders whose activities threaten the rights and interests of individuals, social groups, society and the state.

On the other hand, the difference of really legitimate acts of public authorities and officials from illegitimate consists not only in their restriction with so-called "due process of law" (Bingham, 2011, p. 29), but also in analyzing practicability and efficiency of coercion.

The society are managed by the authorities with both maximum and minimum "power" costs. They allow some degree of self-regulation freedom. Moreover, in a postindustrial society, it is often more effective to use indirect force in each case of committing an offense or the threat of its commission, but rather the redistribution of imperative energy in certain areas of social regulation, depending on the type of social relations.

Thus, Lon Fuller, arguing with supporters who recognizes the use of force as one of the distinguishing features of law, notes, that in many situations, practically, physical coercion and even the very possibility of its use are absent. For example, the state allows foreigners to engage in entrepreneurial activities on its territory only on the condition that they deposit a significant amount in the national bank that guarantees compliance with the rules of law applied in their field of activity. If they commit a violation of any of these norms, the state, in accordance with the court decision, will impose a fine in the form of a deduction from the deposit of the foreign entrepreneur. In other words, it is referred to a simple accounting operation. According to Lon Fuller, it would be a mistake to refuse call such a system "right", because the state did not have an opportunity to use force or threaten to use force, to force its requirements (Fuller, 1969, 87). We believe that he confuses here the concepts of "use of force" and "coercion," but he correctly notes that the rule of law tends to rationally and efficiently distribute imperative energy in the process of social regulation.

Otherwise, the state power achieves their goals by abusing power in the form of violence. From this point of view it is necessary to recognize as fair the conclusion to which Lon Fuller comes. In his opinion, one could rightly refuse to call this system "legal" if it turned out that the published laws and the judges dressed in the mantle are just a facade that in fact hides an unlawful act of confiscation (Fuller, 1969, 87).

A legislator "redirects" the excessive coercive energy of state power from certain branches (institutions) of law to others, where it is more appropriate. At the same time, he keeps it as needed for the right not to turn into a facade 
that covers the arbitrary rule. Therefore, in some branches of law in connection with the peculiarities of the legal regimes that are inherent in them, state coercion resides, as it were, in a latent form.

It should be highlighted that in situations similar to the modeled by Lon Fuller, state coercion is not simply hidden. Herein legal coercion comes to the forefront. It is most clearly appeared when a legal conflict is resolved without using the mechanism of state coercion. However, the latter remains valid and can be used, if the coercive power of law is not sufficient to resolve the conflict.

This feature of legal coercion has long attracted the attention of jurists who adhere to the notion of natural coercion of law. Its supporters connect the legal power provisions with the authority of law and its public recognition. They understand by the term "force of law" the need of the subject of law to organize their social life on the recognition of the idea of law basis as an unconditional imperative of its activity, as well as the activities of other subjects of law.

In our opinion, such a concept is not entirely correct. In fact, by "naturalness" here is meant not the specificity of the ontological grounds of a special type of coercion - legal coercion, but more common (in comparison with the implementation of state coercion measures) procedure for resolving the conflict between subjects of law. This means that the ontological grounds of legal coercion are not "natural" by their nature, but social. Of course, legal coercion, as Lon Fuller and Sergey Alekseev note, and state coercion are social phenomena. Whereas, as manifested in specific situations, the so-called "natural coercion of law", in fact, is a result that based on the preliminary calculation of the imperative energy distribution of state power in the spheres of public life.

It is our first remark that can be conditionally called "technical", as it refers to the technology of state coercion enforcement, mediated by the right. The coercion legitimacy (its legitimacy, justice), and not only its legality, depends on the prior application of coercive measures of their distribution by the branches of law and within each legal branch - according to its structural subdivisions (institutions).

Thus, the acceptance of the state coercion, use in the sphere of legal regulation of public relations, is conditioned by the calculation of all benefits and implications, the appropriateness and effectiveness, the costs of its application. In the common language, this legitimacy condition of state coercion is expressed in statements about "rigidity", even "cruelty" or, on the contrary, "softness", "humanity" of the current legislation and practice of its application by the court and law enforcement agencies - in the final analysis, their justice or injustice.

The next remark is - in a democratic society, the mechanism of state coercion mediated by law must be integrated into the structure of the legal system at the baseline. However, herein a problem about measures correlation of state coercion with the structural elements of the legal norm arises.

On the one hand, it would be quite logical to assume that the measures of state coercion find their expression in the sanction of the law norms. Actually, this appears when coercive measures are applied on the basis of a relevant act to persons guilty of committing offenses, if their guilt is proven in accordance with the procedure established by law. These measures are structurally isolated and clearly expressed in the legal norm.

On the other hand, competent state authorities and officials also apply such state coercion measures that are focused on preventing the commission of offenses or on the guaranty of restoration of the violated right and the realization of legal rights. Obviously, such coercive measures contain additional restrictions; they fall within the competence of the state and are applied for order processing in the public relations regulated by law. Nevertheless, they can be applied even in the absence of offenses. For example, administrative detention; delivery; pat search; things inspection; vehicle inspection; inspection of corporate premises, territories; seizure of things and documents; transport arrest and etc. 
The International Journal

ENTREPRENEURSHIP AND SUSTAINABILITY ISSUES

ISSN 2345-0282 (online) http://jssidoi.org/jesi/

2018 Volume 6 Number 2 (December)

http://doi.org/10.9770/jesi.2018.6.2(23)

In our opinion, such measures of state coercion find their legal expression not in sanctions, but in dispositions of legal standards. Moreover, these measures, firstly, do not imply direct contradiction to the interests, desires and will of the coerced subject, although they do not exclude it. Secondly, they transcend the conceptual understanding of state coercion as a reaction of the state to the illegal behavior of subjects of law. However, they remain within the limits of the normative (legal) measurement of state coercion. The legislation analyzing allows us to conclude that the measures of state coercion are non-uniform. In accordance with the concept of saving the distribution of imperative power, they can take the following form: legal liabilities (mulctary), or protection measures, security measures (preventive).

Finally, the third remark relates to the legal status of the coerced subject. In essence, the content of coercive subjects' rights and obligations is the right and obligation to subject the coerced subject to coercive action and apply appropriate state coercion measures to it. However, coerced subjects are also endowed with legal rights and duties. They are obliged to undergo various legal restrictions of personal, property or organizational nature, which contain measures of state coercion. Herewith, they have the ability to require compliance with the procedure for the application of these measures and their implementation in the rule of law. All subjects to relation of which uses the state coercion measures, are authorized by rights and duties that indicate the state takes under the protection of the law their rights and freedoms, interests. There is a legal restriction of state coercion, as a result of which it must comply with the requirements of legality, legitimacy and justice at all stages of its application from consolidation in the law to achieving the set goals.

\section{Conclusions}

In consequence of the acceptance criterion of the state coercion research, we arrive at the following conclusions. Thus, the general acceptance criterion of state coercion is its compliance with the requirements of justice as a moral category. The structural elements of this criterion are validity and proportionality. Their differentiation in content allows us to assert that validity means the causation of state coercion by law. Proportionality is the correlation of state coercion with individualizing circumstances that allow one to correct the effect of the coercive subject on the options enforced in accordance with the proposed law and taking into account the specifics of the concrete case.

The acceptance of state coercion is determined formally and materially. The formal definition of the acceptance of state coercion is the same as the definition of the application of state coercion foundations in the narrow sense. We are talking about legislative consolidation material and procedural norms of law, containing requirements for the state coercion. They reflect the results of the pre-estimate calculation and distribution of the imperative energy of power conducted by the legislator in the main areas of legal regulation of public relations.

The material definition of the acceptance of state coercion is derived from a broad understanding of law, which is unlimited by a set of norms expressed in legislation. From this point of view, the conformity of state coercion measures and their application to the moral ideals of society is also assessed through direct (operative) expression by members of society attitude to state coercion as a form of state power realization in each concrete case. Let us emphasize once again, that the discussed problems are especially acute when the interests of the state are directly colliding in the whole variety of its bodies and officials, and of an individual or persons opposed to it. Being in the field of scientists view, the legal restriction mechanisms of state power and the individual's real opportunity to realize their rights and interests guarantee, receive their conceptual design.

Then, the legislator chooses from the existing concepts those that, in his opinion, are most consistent with the level of socio-economic, political, cultural and moral development of society, and fixes them in normative acts. Thus, the government has a standard dimension. The standard dimension of power enriching with ideas about the 
proper behavior of a person, about justice, morality, humanism, prevailing in a concrete society, becomes legal in the broadest sense of the word. As a result, a legal dimension of such a form of exercising state power is shaped as the state coercion that meets the requirements of modern society.

\section{References}

Ambrose, Y. K. Lee. 2014. Legal Coercion, Respect \& Reason-Responsive Agency, Ethical Theory and Moral Practice 17: 847-859. http://doi.org/10.1007/s10677-013-9486-4

Armstrong, C. 2009. Coercion, reciprocity, and equality beyond the state, Journal of Social Philosophy 40: 297-316. https://doi.org/10.1111/j.1467-9833.2009.01454.x

Arneson, R. 2003. Equality, coercion, culture and social norms, Politics, Philosophy and Economics 2: 139-163. $10.1177 / 1470594 X 03002002001$

Bingham, T. 2011, The Rule of Law. London, The Great Britain: Penguin.

Carrithers, D.W. 1998, Montesquieu's philosophy of punishment, History of Political Thought 19(2): 213-240.

Finnis, J. 2011, Natural Law and Natural Rights. London, The Great Britain: Oxford University Press.

Fuller, L.L. 1969. The Morality of Law, New Haven, USA: Yale University Press.

Gargarella, R. 2011, Penal Coercion in Contexts of Social Injustice? Criminal Law and Philosophy 5: 21-38. https://doi.org/10.1007/s11572-010-9107-4

Green, L. 2015. The Forces of Law: Duty, Coercion and Power, Oxford Legal Studies Research 12: 1-33.

Hardin, R. 1989-1990. Rationally Justifying Political Coercion, Journal of Philosophical Research 15: 79-91.

Himma, K.E. 2012. Coercive Enforcement and a Positivist Theory of Legal Obligation, The Annals of the Faculty of Law in Belgrade Belgrade Law Review, Year LIX 3: 216-242.

Hughes, R.C. 2013. Law and Coercion, Philosophy Compass 8(3): 231-240. https://doi.org/10.1111/phc3.12013

Kuril, J. 2018. Public administration for safe and secure environment: case of Slovak Republic, Entrepreneurship and Sustainability Issues 5(3): 493-501. https://doi.org/10.9770/jesi.2018.5.3(6)

Lamond, G. 2001. Coercion and the Nature of Law, Legal Theory 7: 35-57.

Leiser, B.M. 2008. On Coercion, in D.A. Reidy, W.J. Riker (ed.) Coercion and the State, Springer Netherlands, 31-43.

Lloyd, D. 1991. The Idea of Law, London, The Great Britain: Penguin Books Ltd.

Mishenin, Y.; Koblianska, I.; Medvid, V.; Maistrenko, Y. 2018. Sustainable regional development policy formation: role of industrial ecology and logistics, Entrepreneurship and Sustainability Issues 6(1): 329-341. https://doi.org/10.9770/jesi.2018.6.1(20)

Munger, M.C. 2012. Coercion, the State, and the Obligations of Citizenship, Public Choice 152(3/4): 415-421. https://doi.org/10.1007/s11127-012-9992-2

Načisčionis, J.; Skrastiņa, U.; Tumalavičius, V. 2018. Secure development of public administration, Journal of Security and Sustainability Issues 8(1): 87-102. https://doi.org/10.9770/jssi.2018.8.1(8)

Raponi, S. 2015. Is Coercion Necessary for Law? The Role of Coercion in International and Domestic Law, Washington University Juridical Review 35: 35-58. https://openscholarship.wustl.edu/cgi/viewcontent.cgi?article=1132\&context=law_jurisprudence 
The International Journal

ISSN 2345-0282 (online) http://jssidoi.org/jesi/

2018 Volume 6 Number 2 (December)

http://doi.org/10.9770/jesi.2018.6.2(23)

Ripstein, A. 2004. Authority and Coercion, Philosophy \& Public Affairs 32(1): 2-35. https://poseidon01.ssrn.com/delivery.php?ID=35001706400308712106910209708010011909701408808701600403110507203008900006 $\underline{6070009030032012051099111045001111067014081117076022058073017052065022070010121016024095004076031119122071113115}$ $\underline{083026120112083076079083076073091118024022115064065119107086124 \& E X T=p d f}$

Schauer, F. 2014. The Force of Law, Cambridge, The Great Britain: Cambridge University Press.

Stavropoulos, N. 2009. The Relevance of Coercion: Some Preliminaries, Ratio Juris 22: 339-358.

Tvaronavičienė, M; Gatautis, R. 2017. Peculiarities of income distribution in selected countries, Economics and Sociology 10(4): 113-123. https://doi.org/10.14254/2071-789X.2017/10-4/9

Tvaronavičienè, M. 2018. Preconditions of sustainable entrepreneurship: estimating of Brexit scenarios' impact on macroeconomic environment, Polish Journal of Management Studies 17 (2): 222-234 https://doi.org/10.17512/pjms.2018.17.2.19

Tyler, T. 1990. Why People Obey the Law, New Haven, USA: Yale University Press.

Valentini, L. 2011. Coercion and Justice, American Political Science Review 105: 205-220. https://philpapers.org/rec/VALCAG

Weber, M., Parsons, T. \& Henderson, A.M. 2012. The Theory of Social and Economic Organization, Reprint of Original 1947 Edition, New York, USA: The Free Press.

Wollner, G. 2011. Equality and the Significance of Coercion, Journal of Social Philosophy 42: 363-381. https://doi.org/10.1111/j.14679833.2011.01539.x

Yankah, E.N. 2007-2008. The Force of Law: The Role of Coercion in Legal Norms, University of Richmond Law Review 42(5): 11951217.

Zwolinski, M. 2015. Property Rights, Coercion, and the Welfare State: The Libertarian Case for a Basic Income for All, The Independent Review 19(4): 515-529. http://www.independent.org/pdf/tir/tir_19_04_04_zwolinskif.pdf

\section{Olga FINOGENTOVA}

Institute of Law, Immanuel Kant Baltic Federal University, Kaliningrad, Russiau

ORCID ID: 0000-0003-4568-9764

\section{Vasiliy TOKAREV}

Samara State Regional Academy, Samara, Russia

ORCID ID: 0000-0001-5281-5517

Mikhail PETRENKO

International Market Institute, Samara, Russia

ORCID ID: 0000-0002-0046-6754

\section{Tatyana PRIMAK}

Institute of Law, Immanuel Kant Baltic Federal University, Kaliningrad, Russia

ORCID ID: 0000-0003-4101-1112

Register for an ORCID ID:

https://orcid.org/register

Copyright (C) 2018 by author(s) and VsI Entrepreneurship and Sustainability Center

This work is licensed under the Creative Commons Attribution International License (CC BY).

http://creativecommons.org/licenses/by/4.0/

(c) (i) Open Access 
The International Journal

ENTREPRENEURSHIP AND SUSTAINABILITY ISSUES

ISSN 2345-0282 (online) http://jssidoi.org/jesi/

2018 Volume 6 Number 2 (December)

http://doi.org/10.9770/jesi.2018.6.2(23) 